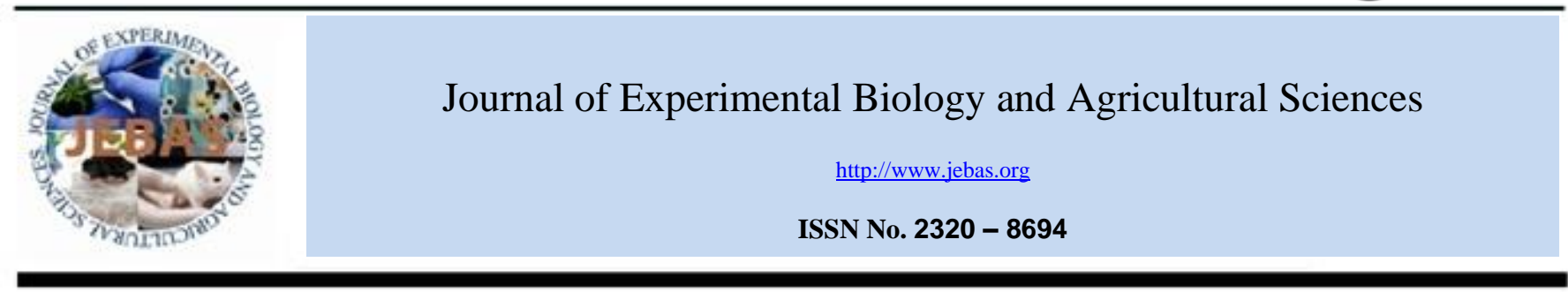

\title{
HAEMATO-BIOCHEMICAL, RADIOGRAPHIC AND CLINICAL OUTCOME IN HEALING OF FEMORAL FRACTURE WITH RETROGRADE INTRAMEDULLARY PIN IN CONJUNCTION WITH DEMINERALIZED BONE MATRIX IN DOGS
}

\author{
Singh $\mathrm{C} \mathrm{K}^{1, *}$, Sarma K K ${ }^{2}$, Kalita $\mathrm{D}^{3}$, Tamuly $\mathrm{S}^{4}$, Hussain $\mathrm{J}^{5}$, Deuri $\mathrm{B}^{6}$ and Nath $\mathrm{P} \mathrm{J}^{6}$ \\ ${ }^{1}$ MVSc Student, College of Veterinary Science, Khanapara, Assam Agricultural University, Assam,Pin-781022. \\ ${ }_{2}^{2}$ Professor and Head, Department of Surgery and Radiology, College of Veterinary Science, Khanapara, Assam Agricultural University, Assam,Pin-781022. \\ ${ }^{3}$ Associate Professor, Department of Surgery and Radiology, College of Veterinary Science, Khanapara, Assam Agricultural University, Assam,Pin-781022. \\ ${ }^{4}$ Assistant Professor, Department of Veterinary Biochemistry, College of Veterinary Science, Khanapara, Assam Agricultural University, Assam,Pin-781022. \\ ${ }^{5}$ Assistant Professor, Department of Livestock Production and Management, College of Veterinary Science, Khanapara, Assam Agricultural University, \\ Assam,Pin-781022. \\ ${ }^{6}$ Assistant Professor, Department of Surgery and Radiology, College of Veterinary Science, Khanapara, Assam Agricultural University, Assam,Pin-781022.
}

Received - February 26, 2017; Revision - April 21, 2017; Accepted - May 01, 2017

Available Online - May 12, 2017

DOI: http://dx.doi.org/10.18006/2017.5(2).201.207

\section{KEYWORDS \\ Demineralized bone matrix \\ Femoral fracture healing \\ Haemato -biochemical \\ Radiographic}

Clinical outcome

\section{* Corresponding author \\ E-mail: 46161chandan@gmail.com (Singh C K)}

Peer review under responsibility of Journal of Experimental Biology and Agricultural Sciences.

Production and Hosting by Horizon Publisher India [HPI] (http://www.horizonpublisherindia.in/).

All rights reserved.

\begin{abstract}
The study was undertaken to evaluate the haemato-biochemical, radiographic and clinical outcome of femoral fracture healing in dogs. The dogs were treated with open reduction and internal fixation (ORIF) with retrograde intramedullary pin with or without full circlage wire (Group I) and ORIF with retrograde intramedullary pin with or without full circlage wire along with incorporation of demineralized bone matrix (Group II) at the fracture site. The haemato-biochemical, radiographic and clinical outcome assessment were done on $0,21^{\text {st }}, 45^{\text {th }}$ and $60^{\text {th }}$ day. The haemato-biochemical parameters studied were alkaline phosphatase, creatinine kinase, serum calcium, total erythrocyte count, total leucocyte count, haemoglobin, packed cell volume, lymphocyte, monocyte, thrombocyte, mean platelet volume, mean corpuscular volume and mean corpuscular haemoglobin. Modified Thomas splint was applied post operatively till $21^{\text {st }}$ day; dogs started walking from $3^{\text {rd }}$ day onwards. The haematological, radiographic and clinical outcome in the different time period and between the groups showed non-significant minor variation during the period of study. The biochemical activity of alkaline phosphatase was better in group II. On $60^{\text {th }}$ day radiograph showed complete bridging of fracture end with callus in both the group except for one animal of group II. Based on better biochemical activity of alkaline phosphatase in group II and similar haematological, radiographic and clinical outcome it can be concluded that demineralized bone matrix can augment the healing of femoral fracture.
\end{abstract}

All the article published by Journal of Experimental Biology and Agricultural Sciences is licensed under a Creative Commons Attribution-NonCommercial 4.0 International License Based on a work at www.jebas.org.

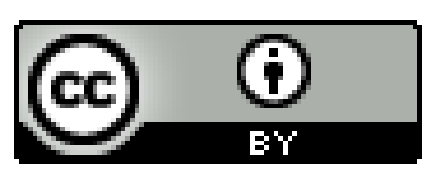




\section{Introduction}

Femur fracture accounts for highest percentage of fracture occurrence in small animals (Simon et al., 2010; Kushwaha et al., 2011). The objective of fracture treatment is to achieve fastest possible healing and enable the patient to early ambulation (Shahar, 2000). Intramedullary pinning is most widely used for internal fixation because it require minimal exposure of the fracture site, speed of insertion, low cost, require less technical expertise and equipment, least sophisticated, resist bending force in all directions, give stronger repair to the fracture site in early stage of healing and its strength is related to its diameter (Newton \& Nunamaker, 1985; Denny \& Butterworth, 2000). Fracture healing is a complex physiological process it involves many types of cells, biochemical regulating factors and expression of several thousand genes (Eihorn, 1998). Demineralized bone matrixes are obtained either from bovine, porcine or human cadaver. It is prepared by pulverization into consistent size followed by decalcification with hydrochloric acid. As a result of decalcification mineral component are lost but retains the Type I collagen, non-collagenous proteins, osteoinductive growth factors including varying concentration of bone morphogenetic proteins (BMPs), growth differentiation factors and other transforming growth factors (TGF-b1, TGF-b2, TGF-b3)(Kale \& DiCesare,1995; Urist et al.,1983; Schwartz et al., 2011; Gruskin et al.,2012; Holt \& Grainer, 2012). The present study was undertaken to evaluate the haemato-biochemical, radiographic and clinical outcome of femoral fracture healing in dogs treated with open reduction and internal fixation (ORIF) with retrograde intramedullary pinning in conjunction with demineralized bone matrix.

\section{Materials and methods}

Twelve dogs irrespective of their age, sex, breed, body weight with history of road traffic accident, fall from height and being hit by iron bar or any other form of trauma presented to the Department of Surgery and Radiology, College of Veterinary Science, Khanapara, Assam Agricultural University were taken into study. These dogs were clinically evaluated, administered preliminary medicinal treatment, care and were subjected for confirmatory diagnosis by radiograph. After confirmatory diagnosis for femoral fracture these dogs were divided into two groups comprising of six animals in each group for treatment as-

Group I- Open reduction retrograde intramedullary pinning with or without full circlage wiring

Group II- Open reduction retrograde intramedullary pinning with or without full circlage wiring along with incorporation of demineralized bone matrix (DBM) in the form of paste at the fracture ends

The dogs were kept off fed for 12 hours and off water for 6 hours respectively. Premedication was done with atropine sulphate at the dose rate of $0.04 \mathrm{mg} / \mathrm{kg}$ bwt intramuscularly 15 minutes prior to administration of xylazine hydrochloride at the dose rate of $1 \mathrm{mg} / \mathrm{kg}$ bwt intramuscularly. Then a combination of diazepam at the dose rate of $0.3 \mathrm{mg} / \mathrm{kg}$ bwt and ketamine hydrochloride at the dose rate of $5 \mathrm{mg} / \mathrm{kg}$ bwt intravenous was used as an induction agent and for maintenance of anaesthesia throughout the surgery as supplemental dose. Retrograde intramedullary pinning covering $60-75 \%$ of the medullary cavity was done and treatment was rendered as per the groups. The surgical wounds were closed in routine manner. External immobilization was done with Modified Thomas splint for three weeks which was changed at regular interval of one week. The post-operative treatment regime comprised of inj. Ceftriaxonesulbactum at the dose rate of $15 \mathrm{mg} / \mathrm{kg}$ b.i.d for 5 days, inj gentamicin at the dose rate of $5 \mathrm{mg} / \mathrm{kg}$ b.i.d. bwt intramusculary for 5 days, inj. butorphanol at the dose rate of $0.2 \mathrm{mg} / \mathrm{kg}$ bwt intramuscularly b.i.d for 5 days and fluid therapy with dextrose in normal saline for 5 days. Three milliliter $(3 \mathrm{ml})$ of blood was collected prior to surgery on 0 and on $21^{\text {st }}, 45^{\text {th }}$ and $60^{\text {th }}$ day for biochemical, haematological study and plain radiograph was taken on same intervals. The dogs were clinically evaluated on $21^{\text {st }}, 45^{\text {th }}$ and on $60^{\text {th }}$ day. The biochemical parameters studied were Alkaline phosphatase (ALP), Creatinine kinase (CK), Serum Calcium (Ca). The alkaline phosphtase was estimated as per the p-nitrophenyl phosphate method from the commercially available kit using UV visible spectrophotometer and expressed as U/L. Creatinine kinase was estimated as per IFCC method from commercially available kit using UV spectrophotometer and expressed as U/L. Serum calcium was estimated by the procedure cresolphthalein complex one method using UV spectrophotometer and expressed as U/L. Haematological parameters studies included Total Erythrocyte Count (TEC), Total Leucocyte Count (TLC), Haemoglobin (Hb), Packed Cell Volume (PCV), Lymphocyte (Ly), Monocyte (M), Thrombocyte (T), Mean Platelet Volume (MPV), Mean Corpuscular Volume (MCV), Mean Corpuscular Haemoglobin $(\mathrm{MCH})$ and were estimated using haemoautoanalyzer.

Statistical analysis was performed by Student t- test and Analysis of variance (ANOVA) using Statistical package of SAS enterprise guide 4.2 with level of significance at $5 \%$.

\section{Results and Discussion}

The alkaline phosphatase (ALP) in group I, showed highly significant difference $(\mathrm{P}<0.01)$ on $21^{\text {st }}$ days and significant difference $(\mathrm{P}<0.05)$ on $60^{\text {th }}$ days (Table 1$)$. While in case of group II highly significant difference $(\mathrm{P}<0.01)$ was observed on $21^{\text {st }}, 45^{\text {th }}$ days and significant difference $(\mathrm{P}<0.05)$ on $60^{\text {th }}$ days (Table 1$)$. Highly significant difference $(\mathrm{P}<0.01)$ was observed on $45^{\text {th }}$ and significant difference $(\mathrm{P}<0.05)$ on $60^{\text {th }}$ days between the group I and group II (Table 1). Higher values were observed in group II on $21^{\text {st }}, 45^{\text {th }}$ and $60^{\text {th }}$ day. Increase in osteoblastic activity indicates normal fracture healing. Large amount of alkaline phosphatase is released by the osteoblast, these alkaline phosphatase leads to formation of bone matrix and its mineralization (Leung et al., 1993). Alkaline phosphatase is supposed to increase the concentration of local inorganic phosphate or neutralize inorganic pyrophosphate (Seropoulos \& Anagnostopoulos, 1997; Volpin et al., 1998). 
Table 1 Value of various haematological and biochemical parameters in studied dogs

\begin{tabular}{|c|c|c|c|c|c|}
\hline \multirow[t]{2}{*}{ Parameters } & \multirow[t]{2}{*}{ Treatments } & \multicolumn{4}{|c|}{ Periods (Days) } \\
\hline & & $\mathbf{0}$ & 21 & 45 & 60 \\
\hline \multirow[t]{2}{*}{ Total Erythrocyte Count } & GROUP I & $5.27 \pm 0.15^{\mathrm{a}}{ }_{\mathrm{A}}$ & $5.68 \pm 0.12^{\mathrm{a}}{ }_{\mathrm{B}}$ & $5.54 \pm 0.14^{\mathrm{a}}{ }_{\mathrm{B}}$ & $5.98 \pm 0.15^{\mathrm{a}}{ }_{\mathrm{B}}$ \\
\hline & GROUP II & $4.09 \pm 0.36^{\mathrm{b}}{ }_{\mathrm{A}}$ & $5.02 \pm 0.47^{\mathrm{a}}{ }_{\mathrm{B}}$ & $5.65 \pm 0.21^{\mathrm{a}}{ }_{\mathrm{C}}$ & $4.66 \pm .79_{\mathrm{A}}^{\mathrm{b}}$ \\
\hline \multirow[t]{2}{*}{ Total Leucocyte Count } & GROUP I & $30.88 \pm 2.83^{\mathrm{a}}{ }_{\mathrm{A}}$ & $22.75 \pm 2.30^{\mathrm{a}}{ }_{\mathrm{A}}$ & $15.80 \pm 3.01^{\mathrm{a}}{ }_{\mathrm{B}}$ & $15.60 \pm .51^{\mathrm{a}}{ }_{\mathrm{B}}$ \\
\hline & GROUP II & $25.07 \pm 3.24_{\mathrm{A}}^{\mathrm{b}}$ & $15.68 \pm 0.75^{\mathrm{b}}{ }_{\mathrm{B}}$ & $15.05 \pm 0.74_{\mathrm{B}}^{\mathrm{a}}$ & $12.65 \pm 1.41^{\mathrm{a}}{ }_{\mathrm{B}}$ \\
\hline \multirow[t]{2}{*}{ Haemoglobin } & GROUP I & $9.45 \pm 0.27^{\mathrm{a}}{ }_{\mathrm{A}}$ & $10.37 \pm 0.22^{\mathrm{a}}{ }_{\mathrm{B}}$ & $10.78 \pm 0.34^{\mathrm{a}}{ }_{\mathrm{B}}$ & $12.22 \pm 0.20^{\mathrm{a}} \mathrm{C}$ \\
\hline & GROUP II & $8.98 \pm 0.87^{\mathrm{a}}{ }_{\mathrm{A}}$ & $9.58 \pm 0.97_{\mathrm{A}}^{\mathrm{a}}$ & $10.20 \pm 0.56^{\mathrm{a}}{ }_{\mathrm{B}}$ & $9.00 \pm 1.53^{\mathrm{a}}{ }_{\mathrm{A}}$ \\
\hline \multirow[t]{2}{*}{ Lymphocyte } & GROUP I & $7.44 \pm 1.61_{\mathrm{A}}^{\mathrm{a}}$ & $7.44 \pm 1.61^{\mathrm{a}}{ }_{\mathrm{A}}$ & $5.19 \pm 1.18^{\mathrm{a}}{ }_{\mathrm{B}}$ & $4.26 \pm 1.14^{\mathrm{a}}{ }_{\mathrm{B}}$ \\
\hline & GROUP II & $3.53 \pm 0.32^{\mathrm{c}} \mathrm{A}$ & $3.53 \pm 0.32^{\mathrm{c}} \mathrm{A}$ & $2.92 \pm 0.34_{\mathrm{A}}^{\mathrm{c}}$ & $1.23 \pm 0.35^{\mathrm{c}}{ }_{\mathrm{B}}$ \\
\hline \multirow[t]{2}{*}{ Monocyte } & GROUP I & $2.07 \pm 0.57^{\mathrm{a}}{ }_{\mathrm{A}}$ & $1.99 \pm 0.12^{\mathrm{a}}{ }_{\mathrm{A}}$ & $1.52 \pm 0.17^{\mathrm{a}}{ }_{\mathrm{A}}$ & $1.07 \pm 0.14^{\mathrm{a}}{ }_{\mathrm{B}}$ \\
\hline & GROUP II & $0.53 \pm 0.06_{\mathrm{A}}^{\mathrm{c}}$ & $0.61 \pm 0.08_{\mathrm{A}}^{\mathrm{c}}$ & $0.58 \pm 0.08^{\mathrm{b}}{ }_{\mathrm{A}}$ & $0.31 \pm 0.07_{\mathrm{B}}^{\mathrm{b}}$ \\
\hline \multirow[t]{2}{*}{ Thrombocyte } & GROUP I & $177.17 \pm 22.88^{\mathrm{a}}{ }_{\mathrm{A}}$ & $177.17 \pm 22.88^{\mathrm{a}}{ }_{\mathrm{A}}$ & $95.50 \pm 16.06^{\mathrm{a}}{ }_{\mathrm{B}}$ & $77.50 \pm 7.68^{\mathrm{a}}{ }_{\mathrm{C}}$ \\
\hline & GROUP II & $163.33 \pm 42.45^{\mathrm{a}}{ }_{\mathrm{A}}$ & $163.33 \pm 42.45^{\mathrm{a}}{ }_{\mathrm{A}}$ & $125.33 \pm 64.14^{\mathrm{c}}{ }_{\mathrm{B}}$ & $47.33 \pm 13.02^{\mathrm{c}}{ }_{\mathrm{C}}$ \\
\hline \multirow[t]{2}{*}{ MPV } & GROUP I & $8.22 \pm 0.31_{\mathrm{A}}^{\mathrm{a}}$ & $8.35 \pm 0.25_{\mathrm{A}}^{\mathrm{a}}$ & $8.38 \pm 0.25_{\mathrm{A}}^{\mathrm{a}}$ & $8.28 \pm 0.35^{\mathrm{a}}{ }_{\mathrm{A}}$ \\
\hline & GROUP II & $7.48 \pm 0.39^{\mathrm{a}}{ }_{\mathrm{A}}$ & $7.03 \pm 0.48_{\mathrm{A}}^{\mathrm{b}}$ & $7.30 \pm 0.62^{\mathrm{a}}{ }_{\mathrm{A}}$ & $6.74 \pm 1.40^{\mathrm{b}}{ }_{\mathrm{B}}$ \\
\hline \multirow[t]{2}{*}{$\mathrm{MCV}$} & GROUP I & $62.73 \pm 1.71_{\mathrm{A}}^{\mathrm{a}}$ & $61.75 \pm 1.86^{\mathrm{a}}{ }_{\mathrm{A}}$ & $59.67 \pm 1.16^{\mathrm{b}}{ }_{\mathrm{B}}$ & $59.60 \pm 0.31^{\mathrm{a}}{ }_{\mathrm{B}}$ \\
\hline & GROUP II & $64.47 \pm 0.32^{\mathrm{a}}{ }_{\mathrm{A}}$ & $61.88 \pm 0.39^{\mathrm{a}}{ }_{\mathrm{A}}$ & $63.05 \pm 0.35^{\mathrm{a}}{ }_{\mathrm{A}}$ & $58.33 \pm 3.48^{\mathrm{a}}$ \\
\hline \multirow[t]{2}{*}{$\mathrm{MCH}$} & GROUP I & $21.37 \pm 0.53^{\mathrm{a}}{ }_{\mathrm{A}}$ & $19.94 \pm 0.51^{a}{ }_{B}$ & $23.70 \pm 2.75_{\mathrm{A}}^{\mathrm{a}}$ & $18.71 \pm 0.71^{\mathrm{a}}{ }_{\mathrm{B}}$ \\
\hline & GROUP II & $18.58 \pm 0.56_{\mathrm{A}}^{\mathrm{b}}$ & $19.57 \pm 0.72^{\mathrm{a}}{ }_{\mathrm{A}}$ & $19.33 \pm 0.27_{\mathrm{A}}^{\mathrm{b}}$ & $19.70 \pm 0.13^{\mathrm{a}} \mathrm{A}$ \\
\hline \multirow[t]{2}{*}{ ALP } & GROUP I & $84.39 \pm 2.71^{\mathrm{a}}{ }_{\mathrm{A}}$ & $190.88 \pm 3.61^{\mathrm{a}}{ }_{\mathrm{C}}$ & $76.85 \pm 6.39^{\mathrm{a}}{ }_{\mathrm{A}}$ & $60.70 \pm 7.39^{\mathrm{b}}{ }_{\mathrm{B}}$ \\
\hline & GROUP II & $59.71 \pm 11.86^{\mathrm{a}}{ }_{\mathrm{A}}$ & $204.48 \pm 9.39^{\mathrm{a}}{ }_{\mathrm{D}}$ & $155.65 \pm 19.54^{c}{ }_{C}$ & $109.27 \pm 19.27^{\mathrm{a}}{ }_{\mathrm{B}}$ \\
\hline \multirow[t]{2}{*}{ Creatinine Kinase } & GROUP I & $184.73 \pm 6.59^{\mathrm{a}}{ }_{\mathrm{A}}$ & $106.87 \pm 14.42^{\mathrm{a}}{ }_{\mathrm{B}}$ & $56.00 \pm 3.23^{\mathrm{a}}{ }_{\mathrm{C}}$ & $23.08 \pm 1.07^{\mathrm{a}}{ }_{\mathrm{D}}$ \\
\hline & GROUP II & $212.21 \pm 22.31^{\mathrm{b}} \mathrm{A}$ & $94.57 \pm 5.98^{\mathrm{a}}{ }_{\mathrm{B}}$ & $47.72 \pm 1.29^{\mathrm{a}}{ }_{\mathrm{C}}$ & $20.39 \pm 0.80_{\mathrm{D}}^{\mathrm{a}}$ \\
\hline \multirow[t]{2}{*}{ Serum Calcium } & GROUP I & $4.62 \pm 1.32^{\mathrm{a}}{ }_{\mathrm{A}}$ & $4.35 \pm 1.31^{\mathrm{a}} \mathrm{A}$ & $7.97 \pm 0.75^{\mathrm{a}} \mathrm{B}$ & $9.70 \pm 1.18^{\mathrm{a}}{ }_{\mathrm{C}}$ \\
\hline & GROUP II & $5.69 \pm 0.31^{\mathrm{a}}{ }_{\mathrm{A}}$ & $4.80 \pm 0.44^{\mathrm{a}}{ }_{\mathrm{A}}$ & $7.98- \pm 0.20^{\mathrm{a}}{ }_{\mathrm{B}}$ & $8.87 \pm 0.06^{\mathrm{a}}{ }_{\mathrm{C}}$ \\
\hline
\end{tabular}

Value given in table represents MEAN \pm SE value; *Mean bearing similar superscript between the groups do not differ significantly ( $a, b, c)$;

**Mean bearing similar subscript between the periods within the group do not differ significantly $(A, B, C, D)$

DBM is osteoinductive and osteoconductive biomaterial it might facilitate new bone formation by allowing the cells in the local environment to undergo phenotypic conversion to osteoprogenitor cells and might provide mechanical support for vascular and bone in growth (Urist et al., 1983; Kale \& Di Cesare, 1995; Albrek \& Johanssen, 2001; Pieske et al., 2009; Schwartz et al., 2011; Gruskin et al., 2012; Holt \& Grainer., 2012). The demineralization process of DBM by hydrochloric acid $(0.6 \mathrm{ml} / \mathrm{litre})$ might enhance the bone morphogenic protein to stimulate local undifferentiated mesenchymal cell to transform into osteoblast (Riley et al., 1996). The greater elevation of alkaline phosphatase in group II in comparison to group I (Table.1) dogs indicates more osteoblastic activity aided by demineralized bone matrix. Fracture healing can be assessed well with alkaline phosphatase however bone specific isoenzyme of alkaline phosphatase (BALP) is specific (Leung et al., 1993). The finding correlates with previous work (Kumar \& Ramakrishna, 1996).

In group I, highly significant difference $(\mathrm{P}<0.01)$ was reported in creatinine kinase on 0 day, $21^{\text {st }}, 45^{\text {th }}$ and $60^{\text {th }}$ day (Table 1). While in case of group II significant difference $(\mathrm{P}<0.05)$ was noticed on $21^{\mathrm{st}}$ day and highly significant difference $(\mathrm{P}<0.01)$ on $45^{\text {th }}$ and $60^{\text {th }}$ day (Table 1). Significant difference $(\mathrm{P}<0.05)$ was observed on 0 day between the group I and group II (Table 1). The initial increase in the level of creatinine kinase within the physiological limit may be attributed to the muscle trauma, swelled area due to trauma, displaced bone fragment, direct trauma leading to fracture (Larsson \& Linden, 1981; Onio et al., 1989) and stress during the fracture healing phase. The external immobilization in the form of Modified Thomas Splint might have attributed to the stress to the animals, as after it removal on $21^{\text {st }}$ day the creatinine kinase level decreased.

Calcium showed significant difference in group I $(\mathrm{P}<0.05)$ on $45^{\text {th }}$ day and highly significant difference $(\mathrm{P}<0.01)$ on $60^{\text {th }}$ day (Table 1). In group II significant difference $(\mathrm{P}<0.05)$ was observed on $45^{\text {th }}$ day and highly significant difference $(\mathrm{P}<0.01)$ on $60^{\text {th }}$ day (Table 1). Comparison between these two groups revealed no difference. The decrease in the level of serum calcium can be attributed to increased urinary excretion after traumatic bone injury (Kumar et al., 1992). The finding correlates with finding of previous study (Struck et al., 1969; Rani \& Ganesh, 2003) however contrary to findings of Kumar \& Ramakrishna (1996); Howard et al. (1945). The increasing trend from $45^{\text {th }}$ day onward of serum calcium in present study was indicative of normal union (Verma \& Singh, 2003). 


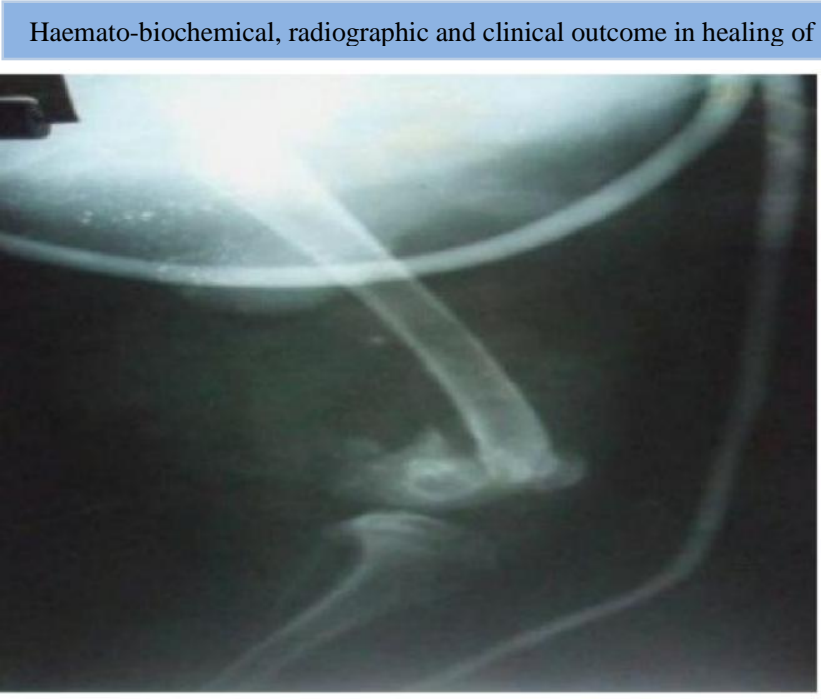

Fig. 10 day (Group I)

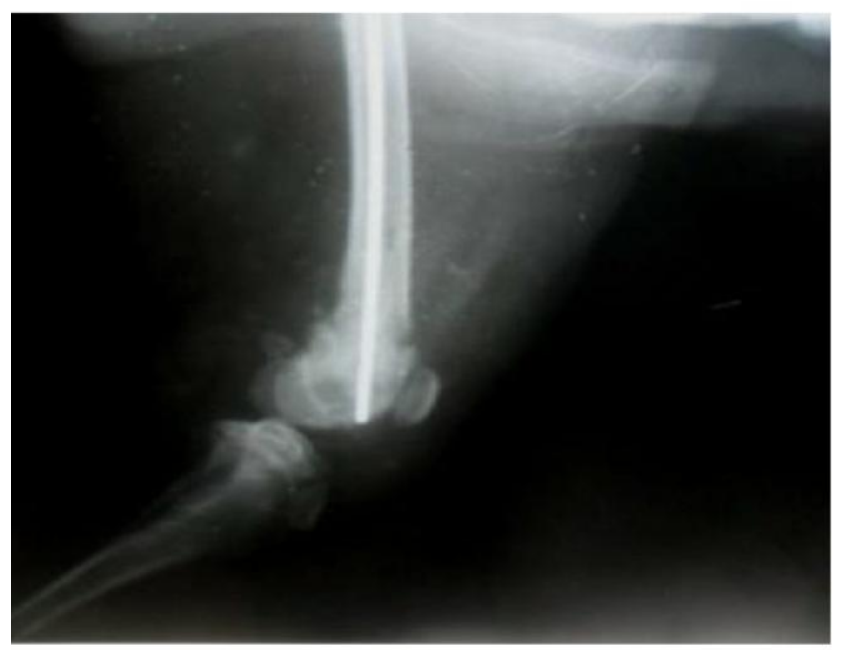

Fig. $321^{\text {st }}$ day (Group I)

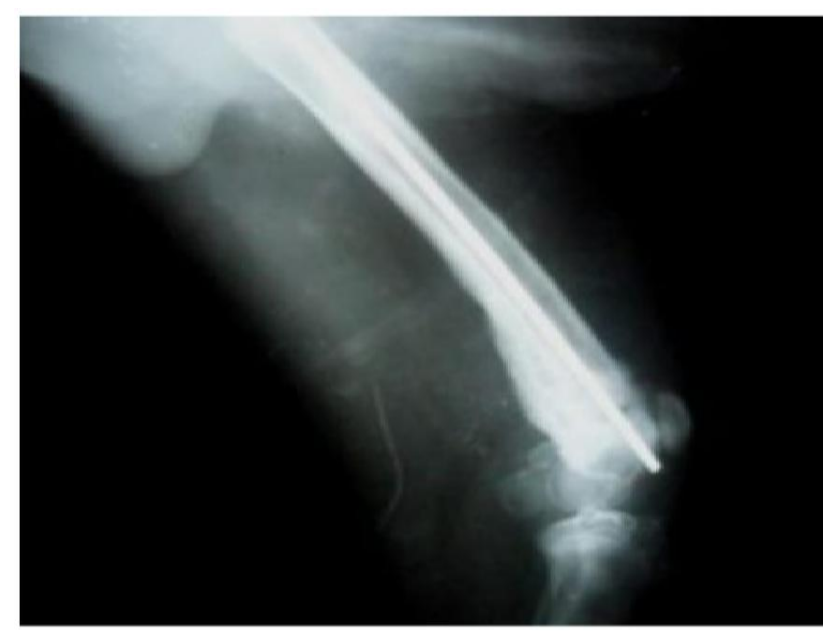

Fig. $54^{\text {th }}$ day (Group I)

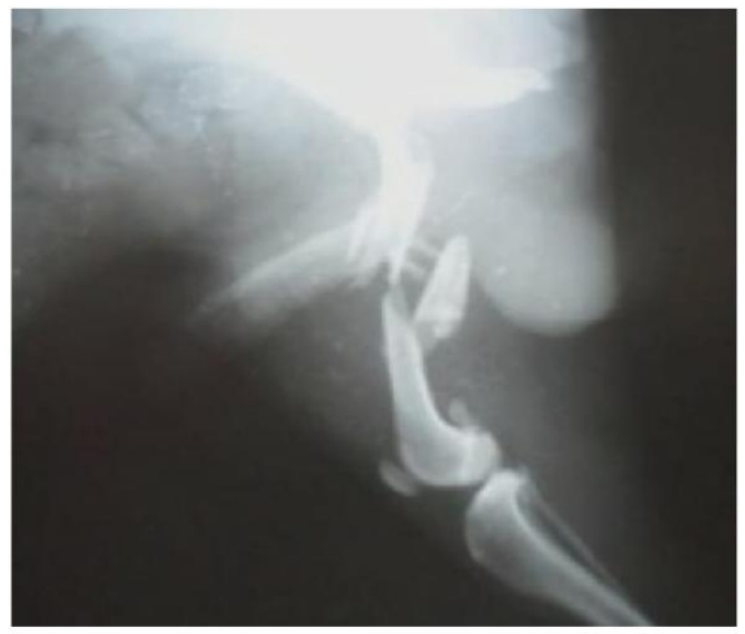

Fig. 20 day (Group II)

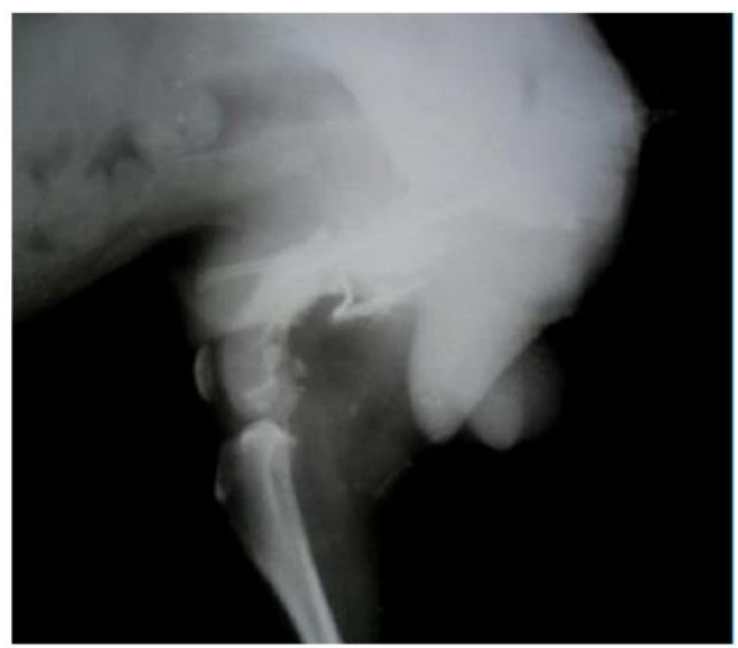

Fig. $421^{\text {st }}$ day (Group II)

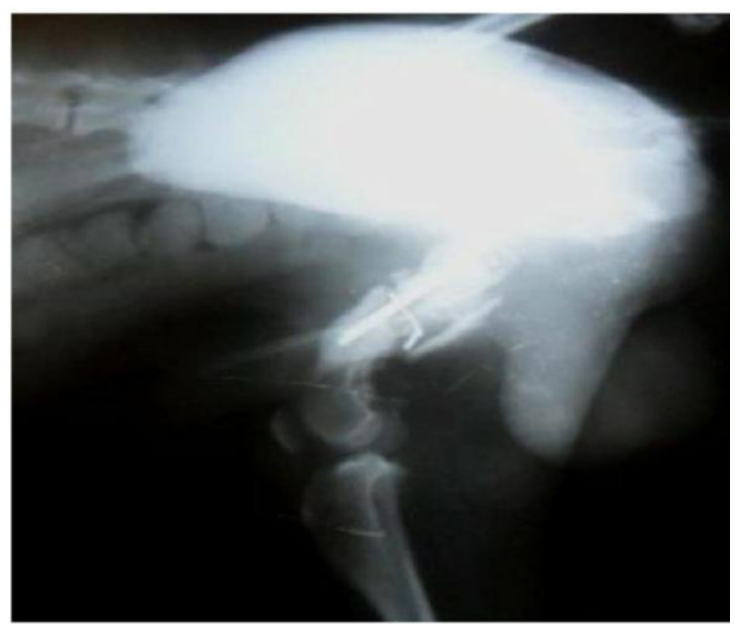

Fig. $645^{\text {th }}$ day (Group II)

Journal of Experimental Biology and Agricultural Sciences http://www.jebas.org 


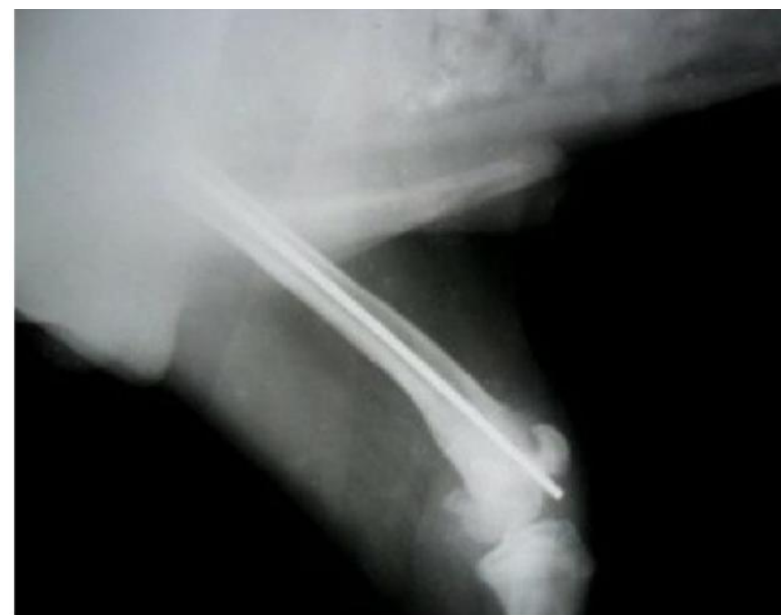

Fig. $760^{\text {th }}$ day (Group I)

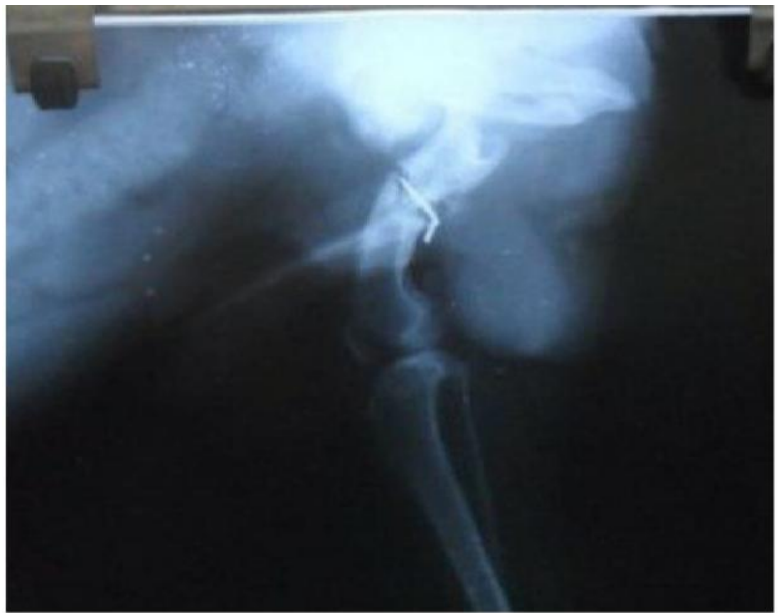

Fig. $860^{\text {th }}$ day (Group II)

Figure1 Showing lateral radiograph on 0 day of complete metaphyseal fracture in a 2 year old, male, Dalmatian dog (Group I); Figure 2 Showing lateral radiograph on 0 day of complete multiple diaphyseal fracture in a 4 year old, male, Pomerian dog (Group II); Figure 3 Showing lateral radiograph on $21^{\text {st }}$ day after intramedullary pin fixation of complete metaphyseal fracture in a 2 year old, male, Dalmatian dog (Group I); Figure 4 Showing lateral radiograph on $21^{\text {st }}$ day after intramedullary pin fixation and full circlage wire fixation in a 4 year old, male, Pomerian dog (Group II); Figure 5 Showing lateral radiograph on $45^{\text {th }}$ day after intramedullary pin fixation of complete metaphyseal fracture in a 2 year old, male, Dalmatian dog (Group I); Figure 6 Showing lateral radiograph on $45^{\text {th }}$ day after intramedullary pin fixation and full circlage wire fixation in a 4 year old, male, Pomerian dog (Group II); Figure 7 Showing lateral radiograph on $60^{\text {th }}$ day after intramedullary pin fixation of complete metaphysesal fracture in a 2 year old, male, Dalmatian dog (Group I); Figure 8 Showing lateral radiograph on $60^{\text {th }}$ day of complete multiple diaphyseal fracture after intramedullary pin fixation and full circlage wire fixation in a 4 year old, male, Pomerian dog (Group II).

Total Erythrocyte Count in group I revealed significant difference $(\mathrm{P}<0.05)$ on $21^{\text {st }}$ and $60^{\text {th }}$ day (Table 1$)$. In group II a significant difference $(\mathrm{P}<0.05)$ was observed on $21^{\text {st }}$ day and highly significant difference $(\mathrm{P}<0.01)$ on $45^{\text {th }}$ day (Table 1). Significant difference $(\mathrm{P}<0.05)$ was noted on 0 and $60^{\text {th }}$ day between the group I and group II (Table 1). The difference between the groups on 0 day might be because of the blood loss in group II dogs as two animals had compound fracture. The TEC in group II did not reached the normal physiological level this can be attributed to the ability of demineralized bone matrix of pooling erythrocytes as they form vascular bed around the fracture site (Pieske et al., 2009; Albrek \& Johanssen, 2001) during the fracture healing stage as by $60^{\text {th }}$ day the value in group I animal reached normal physiological limit.

In group I on $45^{\text {th }}$ day and $60^{\text {th }}$ day significant difference $(\mathrm{P}<0.05)$ was observed in total leucocyte count (Table 1). In group II significant difference $(\mathrm{P}<0.05)$ was observed on $0,21^{\text {st }}, 45^{\text {th }}$ and $60^{\text {th }}$ day (Table 1). Significant difference $(\mathrm{P}<0.05)$ was observed on 0 and $21^{\text {st }}$ day between the group I and group II (Table 1). The increase in the level of TLC in both the groups on 0 day can be attributed to the normal response of body to trauma (Aithal, 1998). The increase in TLC in group I on $21^{\text {st }}$ day can be because of stress to the dogs due to presence of external immobilization or confining the animal to avoid unnecessary movement. Findings of present study correlates with findings of Aithal (1998). The authors in the present study ruled out any infection as none of the animal in the present study developed osteomyelitis and were apparently healthy.

Haemoglobin estimation revealed significant difference in group I $(\mathrm{P}<0.05)$ on $21^{\text {st }}, 45^{\text {th }}$ day and highly significant difference $(\mathrm{P}<0.01)$ on $60^{\text {th }}$ day (Table 1$)$. In group II highly significant difference $(\mathrm{P}<0.01)$ was observed on $45^{\text {th }}$ day (Table 1$)$. Nonsignificant difference was observed between the group I and group II. The group II dogs did not attained the normal physiological level which indicates that the dogs were anaemic. The perusal of literature revealed non availability of literature on role of DBM on haemoglobin. Whether the decrease in haemoglobin is due to DBM or any underlying disease is not clear as the blood were analyzed for haemoprotozoan and ricketssial disease and found negative.

Significant difference $(\mathrm{P}<0.05)$ was observed in Lymphocyte in group I on $45^{\text {th }}$ and $60^{\text {th }}$ day. In group II significant difference $(\mathrm{P}<0.05)$ was observed on $60^{\text {th }}$ day. Highly significant difference $(\mathrm{P}<0.01)$ was observed between the groups on $0,21^{\text {st }}, 45^{\text {th }}$ and $60^{\text {th }}$ day (Table 1). The level of lymphocyte in both the groups throughout the period of study was below the physiological level. Aithal (1998) recorded reduction in the level of lymphocyte till $3^{\text {rd }}$ day of study and concluded that it is normal response of body in early operative days. In the present study it can be attributed to the pain and flight - fright response of the body on 0 day but decrease till $21^{\text {st }}$ day can be attributed to stress, anxiety on the dogs due to the presence of external immobilization. However the level of

Journal of Experimental Biology and Agricultural Sciences http://www.jebas.org 
lymphocyte below physiological limit from $45^{\text {th }}$ to $60^{\text {th }}$ day in both groups remains unexplainable.

Monocyte showed significant difference $(\mathrm{P}<0.05)$ between group I and II on $45^{\text {th }}$ and $60^{\text {th }}$ day however highly significant difference $(\mathrm{P}<0.01)$ was observed on $0,21^{\text {st }}$ days (Table 1). In group I and in group II significant difference $(\mathrm{P}<0.05)$ was observed on $60^{\text {th }}$ (Table 1). In group I increase in the level of monocyte on $0,21^{\text {st }}$ day may be attributed to stress on the animal due to trauma, tissue damage, and external immobilization.

In group I significant difference $(\mathrm{P}<0.05)$ was noted in Thrombocyte on $45^{\text {th }}$ day while highly significant difference $(\mathrm{P}<$ 0.01 ) on $60^{\text {th }}$ day (Table 1). In group II significant difference $(\mathrm{P}<0.05)$ was observed on $45^{\text {th }}$ day and highly significant difference $(\mathrm{P}<0.01)$ was observed on $60^{\text {th }}$ day. Highly significant difference $(\mathrm{P}<0.01)$ was observed on $45^{\text {th }}$ and $60^{\text {th }}$ day between the group I and group II. The values were within normal range in both the group till $21^{\text {st }}$ day and up to $45^{\text {th }}$ day in group II but below normal in group I on $45^{\text {th }}$ and $60^{\text {th }}$ day, and in group II on $60^{\text {th }}$ day. The blood samples were analyzed for haemoprotozoan and rickettsial disease but were found to be negative and the dogs did not have history of any poisoning.

Mean Platelet Volume (MPV) revealed non-significant difference in group I. Significant difference $(\mathrm{P}<0.05)$ was observed on $60^{\text {th }}$ day in group II (Table 1). Significant difference $(\mathrm{P}<0.05)$ was observed on $21^{\text {st }}$ and $60^{\text {th }}$ day between the group I and group II (Table 1). The changes were within physiological limit.

Mean Corpuscular Volume (MCV) revealed significant difference $(\mathrm{P}<0.05)$ in the group I on $45^{\text {th }}$ and $60^{\text {th }}$ day. On $60^{\text {th }}$ day significant difference $(\mathrm{P}<0.05)$ was observed in group II. Between the group I and group II significant difference $(\mathrm{P}<0.05)$ was observed on $45^{\text {th }}$ day. The MCV value in both the group was below the normal physiological value from 0 day and had a declining trend till $60^{\text {th }}$ day. There are no available literatures describing about role of DBM on MCV. The finding indicates that the dogs were having anaemia in both the groups.

In group I significant difference $(\mathrm{P}<0.05)$ was observed in mean corpuscular haemoglobin $(\mathrm{MCH})$ on $21^{\text {st }}$ and $60^{\text {th }}$ day (Table 1). In group II non-significant difference was observed. Significant difference $(\mathrm{P}<0.05)$ was observed between the group on 0 and $45^{\text {th }}$ day (Table 1). There are no available literatures describing role of DBM on $\mathrm{MCH}$ however findings indicates that the dogs were having anaemia in both the groups.

The preoperative radiograph in both the group revealed clear fracture end (Figure 1,2). Radiograph taken post operatively in both the groups showed proper reduction, good alignment of both the fractured ends; with a clear fracture line in between the bone fragments without any angulations or displacement of the fragment as the small fragment were immobilized using full circlage wire. On $21^{\text {st }}$ day the radiograph showed irregular border and feathery appearance, periosteal callus around the fracture site with little formation of callus at the site of fracture in both the groups (Figure
3 , 4). On $45^{\text {th }}$ day radiograph revealed intense callus almost completely bridging the fracture end (Figure 5) in both the groups except one patient of group II with comminuted fracture having three fragments (Figure 6). On $60^{\text {th }}$ day the fracture was completely bridged with callus (Figure 7) except in one patient of group II (Figure 8 ). The non-complete bridging of callus by $60^{\text {th }}$ day might have resulted due to mechanical obstruction by full circlage wire during healing phase (Figure 8). Two patients had pin migration by $60^{\text {th }}$ day comprising one animal from each group. The intramedullary pins were removed in both the groups on $60^{\text {th }}$ day.

The animals of both the groups started walking from the third day onwards. The Modified Thomas splint was changed at one week interval up to third week. It was done to avoid skin damaged because of cotton padding as it causes increase in temperature to the local tissue and increased tissue perspiration. As increase in humidity and tissue perspiration can moisten the cotton and it can become a good media for fungal and bacterial growth. It also aided in inspection of wound and also letting the animal bear it weight on the affected limb and mobilizing the limb for a short period of time. After removal of Modified Thomas Splint on third week, the animals were able to completely bear weight and walk normally with the affected limb though stiffening of gait was observed in 3 animals. These were corrected with physiotherapy session for thrice a week. However one animal of group II was partially weight bearing and hence the Modified Thomas splint was applied up to $45^{\text {th }}$ day. In this animal the callus did not bridged by $60^{\text {th }}$ day and had limb shortening (Figure 8).

\section{Conclusion}

The present study revealed that in both the group haematological, radiographic and clinical outcome were similar. The alkaline phosphatase showed better biochemical activity in group II. Therefore femoral fracture repaired with ORIF along with incorporation of demineralized bone matrix may aid in healing of femoral fracture during the biochemical phases of fracture healing.

\section{Ethical Approval}

The present study was approved by Institutional Animal Ethics Committee.

\section{Conflict of interest}

Authors would hereby like to declare that there is no conflict of interests that could possibly arise.

\section{Reference}

Aithal HP (1998) Modified technique of single pin fixation and cross intramedullary pin fixation technique for supra-condylar femoral fracture in dogs: A comparative study. Indian Journal of Veterinary Surgery $19: 84-89$.

Albrek T, Johanssen C (2001) Osteoinduction, osteoconduction and osteointegration. European Spine Journal 10 : 96-101. 
Denny HR, Butterworth SJ (2000) Options in fracture management. A guide to canine and feline orthopaedic $4^{\text {th }}$ edn Wiley Online library, pp112.

Eihorn TA (1998) The cells and molecular biology of fracture healing. Clinical Orthopaedic Related Research 355: 7-21.

Gruskin E, Doll BA, Futrell FW, Schmitz JP, Hollinger JO (2012) Demineralized bone matrix in bone repair: history and use. Advanced Drug Delivery Reviews 64 : 1063-1077.

Holt DJ, Grainer DW (2012) Demineralized bone matrix as a vehicle for delivering endogenous and exogenous therapeutics in bone repair. Advanced Drug Delivery Reviews 64: 11231128 .

Howard JE, Parson W, Bigham Jr RS (1945) Studies on patients' convalescent from fracture.111. The urinary excretion of calcium and phosphorus. John Hopkin Hospital Bulletin 77: 291-313.

Kale AA , Di Cesare PE (1995) Osteoinductive agents. Basic science and clinical application. American Journal of Orthopaedics 24: 752-761.

Kumar R, Gill PS, Singh R, Setia MS, Rattan PJS (1992) Plasma electrolyte changes during fracture healing in dogs. Indian Veterinary Journal 69: 476-477.

Kumar RVS, Ramakrishna O (1996) Biochemical changes during femoral defect healing with demineralised bone matrix implant in canine. Indian Veterinary Journal 73: 1253-1256.

Kushwaha RB, Gupta AK, Bhadwal MS, Kumar S, Tripathi AK (2011) Incidence of fractures and their management in animals: a clinical study of 77 cases. Indian Journal of Veterinary Surgery 32: 54-65.

Larsson K, Linden WV (1981) Creatinine kinase in tibial shaft fracture. Arch. Orthop. Trauma Surgery 98: 41- 43.

Leung KS, Fung KP, Sher AHL (1993) Plasma bone specific alkaline phosphatase as an indicator of osteoblastic activity. Journal of Bone and Joint Surgery of America 75 : 288-292.

Newton CD, Nunamaker DM (1985) Textbook of Small Animal Orthopaedics. J. B. Lippincott. Philadelphia.

Onio OO, Fenton A, Iqbal SJ, Gregg PJ (1989) Prognostic indicators in tibial shaft fractures: Serum creatinine kinase activity. Journal of Orthopaedic Trauma 3 : 345-347.
Pieske O, Wittmann A, Zaspel J, Loffler T, Rubenbauer B, Trentzsch H, PiltzS (2009) Autologous bone graft versus demineralized bone matrix in internal fixation of ununited long bones. Journal of Trauma Management and Outcome 3:11.

Rani UR , Ganesh TN (2003) Study of calcium, phosphorus and alkaline phosphatase during fracture healing of femur of goat. Indian Veterinary Journal 80: 377-378.

Riley EH, Lane JM, Urist MR, Lyons KM, Lieberman JR (1996) Bone morphogenic protein-2: biology and application. Clinical Orthopaedics Related Research 324: 39-46.

Schwartz Z, Hyzy SL, Moore MA, Hunter SA, Ronholdt CJ, Sunwoo M, Boyan BD (2011) Osteoinductivity of Demineralized Bone Matrix is Independent of Donor Biphosphate Use. Journal of Bone and Joint Surgery 93 : 22782286.

Seropoulos NK, Anagnostopoulos D (1997) Ectopic bone formation in a child with a head injury: complete regression after immobilization. International Orthopaedics 21: 412-414.

Shahar R (2000) Relative stiffness and stress of type I and type II external fixators: Acrylic versus stainless stell connecting bars- a theoretical approach. Veterinary Surgery 29: 59-69.

Simon S, Ganesh R, Ayyappan S, Rao GD, Kumar SR, Kundaye and Da (2010) Incidences of pelvic limb fractures in dogs. Veterinary World $3: 120-121$.

Struck H, Dabew D, Hernandez-Richter HJ, Benfer J (1969) Klinischemische Befundeim Serum beiexperimenteller Fraktursetzung and verschiedener Be- handlung. Enzymologia Biologica et Clinica 10: 463.

Urist MR, Delange RJ, Finerman GA (1983) Bone cell differentiation and growth factor. Science 220: 680-686.

Varma HS, Singh N (2003) Changes in values of serum calcium, serum phosphates and serum alkaline phosphatase following polytrauma. Indian Journal of Orthopaedics 37 : 276277.

Volpin G, Rees JA, Ali SY (1998) Distribution of alkaline phosphatase activity in experimentally produced callus in rats. Journal of Bone and Joint Surgery of America 68 : 629-634. 